\title{
Prevelance of Emeria Genera Upon Coccidiosis Infection Toward Male Layer
}

\author{
Emantis Rosa ${ }^{1)}$, Nadia Eka Yulian"), Purnama Edy Santosa ${ }^{2)}$ \\ ${ }^{1}$ Jurusan Biologi FMIPA, Universitas Lampung, \\ 2. Jurusan Peternakan FP, Universitas Lampung, \\ Jl. Prof. Dr. Soemantri Brojonegoro No. 1, Bandar Lampung, Indonesia 35145 \\ *E-mail: nadiaekay@gmail.com
}

\begin{abstract}
Chicken is one of the bird species used as a source of animal protein which is very enjoyable and known by society. One chicken species that widely cultivated are the male layer. However, there was frequently obstacle in the maintenance, one is caused by parasite species of coccidia that causes coccidiosis. This research is conducted in November 2016 on a livestock farm, Kelurahan Segalamider, Kecamatan Tanjung Karang Barat, Kota Bandar Lampung. This research aims to determine the type of parasite egg that causes coccidiosis and to determine the prevalence of coccidia attack on the male layer. This research uses a proportionate clustered random sampling method, which took 100 samples of the male layer faces randomly from each cage as much as 25 samples. The identification using the guide book of Conway and McKenzie (2007) and the calculation of the number of parasite eggs using EPG Mc. Master assay in Balai Veteriner Lampung. Data were analyzed descriptively by displaying data in tables and figures. The result showed that there are five species of Eimeria, namely Eimeria tenella, Eimeria maxima, Eimeria brunetti, Eimeria nikamae, and Eimeria mitis that found in oocyst sporulated form and oocyst not sporulated. The parasite causes coccidiosis in the male layer is Eimeria tenella with prevalence values of coccidia attack by $20 \%$.
\end{abstract}

Key words : male layer, coccidia, eimeria

\section{PENDAHULUAN}

Ternak unggas mempunyai peran yang sangat penting dalam memenuhi sumber protein dan sumber pendapatan masyarakat Indonesia. Ternak unggas dapat dijadikan sebagai penyediaan daging dan telur yang relatif murah, cepat dihasilkan dan terjangkau untuk masa mendatang dibandingkan dengan ternak lainnya (Dinas Peternakan dan Kesehatan Hewan, 2010).

Ayam petelur jantan sangat mudah dalam pemeliharannya, karena selain bibit nya yang murah dan mudah didapat, pertumbuhannya cepat, memiliki tekstur daging yang menyerupai ayam kampung, memiliki daya adaptasi yang tinggi terhadap berbagai situasi lingkungan dan iklim yang ada dapat dipanen dalam waktu yang singkat, yaitu selama delapan minggu, sehingga banyak diminati oleh masyarakat (Yusdja, 2002). Menurut Suratman (2009), sistem pemeliharaan ayam saat ini sudah mengalami perkembangan yang lebih baik, namun dalam pemeliharaannya banyak terdapat kendala yang menyebabkan perkembangan ayam menjadi terhambat. Salah satu kendalanya adalah adanya berbagai jenis agen penyakit, baik yang disebabkan oleh bakteri, virus, protozoa, maupun cacing.

Dampak penyakit yang ditimbulkan merupakan kendala utama bagi para peternak ayam. Salah satu penyakit akibat protozoa parasit yang menyerang ayam adalah koksidiosis. Koksidiosis merupakan penyakit berak darah yang disebabkan oleh protozoa yang dapat merusak saluran pencernaan pada ayam. 
Informasi tentang kasus koksidiosis di Provinsi Lampung sampai saat ini belum banyak diperoleh. Berdasarkan hal tersebut perlu dilakukan penelitian yang bertujuan untuk mengetahui jenis parasit penyebab koksidiosis pada ayam petelur jantan dan mengetahui prevalensi serangan koksidia pada ayam petelur jantan. Dengan diketahuinya infeksi koksidiosis pada ayam khususnya ayam petelur jantan akan mempermudah penanganan dan pencegahannya lebih dini.

\section{METODE PENELITIAN}

\section{Alat dan Bahan}

Peralatan yang digunakan dalam penelitian ini adalah kertas label, mikroskop, gelas ukur, beaker glass, kamera, masker, sarung tangan, alat tulis, stopwatch, timbangan analitik, termometer, higrometer saringan 200 mesh, batang pengaduk, mortar, pipet tetes, spatula, kamar hitung Mc.Master, dan tisu. Bahan yang digunakan dalam penelitian ini adalah feses ayam dan larutan $\mathrm{NaCl}$ jenuh.

\section{Metode}

Sampel feses ayam diambil sebanyak 100 sampel dari keseluruhan empat kandang yang ada di peternakan mandiri menggunakan metode proportionate clustered random sampling, yaitu diambil feses sebanyak 25 sampel secara acak dari setiap kandang. Sampel feses yang didapat dimasukkan kedalam plastik dan diberi label 1 sampai 100. Kemudian, sampel feses ayam ditimbang sebanyak 2 gram menggunakan timbangan analitik. Sampel feses dihancurkan dengan menggunakan alat tumbuk (mortar) sambil ditambahkan $\mathrm{NaCl}$ jenuh sebanyak $58 \mathrm{~mL}$ sedikit demi sedikit. Kemudian filtrat feses disaring ke dalam beaker glass. Filtrat dalam beaker glass dimasukkan ke dalam kaca Mc.Master menggunakan pipet tetes, tunggu hingga 5 menit sebelum diamati di bawah mikroskop dengan perbesaran 10x. Diidentifikasi dan dihitung jumlah koksidia di bawah mikroskop. Untuk proses identifikasi menggunakan buku panduan
Conway and McKenzie (2007), dengan menyamakan bentuk morfologi berupa ukuran dan bentuk telur parasit koksidia yang ditemukan dan untuk proses penghitungan jumlah koksidia mengikuti rumus menurut Colville (1991) :

$$
\text { Jumlah Ookista per Gram }=100 \mathrm{X}
$$

Keterangan $: \mathrm{X}=\underset{\text { Jumlah ookista yang }}{\text { ditemukan }}$

\section{Analisis Data}

Data yang diperoleh dianalisis menggunakan analisis deskriptif. Hasil identifikasi yang diperoleh disajikan dalam bentuk gambar yang meliputi jenis parasit. Data prevalensi disajikan dalam bentuk tabel yang meliputi jenis, jumlah dan prevalensi. Untuk menghitung prevalensi digunakan rumus menurut Soulsby (1986) sebagai berikut :

$$
\begin{array}{ll}
\text { Prevalensi }=\quad \begin{array}{l}
\text { Jumlah sampel feses } \\
\text { yang ditemukan } \\
\text { suatu jenis }
\end{array} \\
{\cline { 2 - 2 }} \begin{array}{l}
\text { Jumpel yang } \\
\text { samperiksa } \\
\text { diperis }
\end{array} }
\end{array}
$$

\section{HASIL DAN PEMBAHASAN}

Hasil identifikasi 100 sampel feses dapat dilihat pada Tabel 1. Pada Tabel 1. hasil identifikasi ditemukan jenis Eimeria yang beragam, hal ini diduga karena kondisi kandang ayam yang kotor. Kondisi kandang yang kotor ini dikarenakan kandang tempat pengambilan sampel penelitian menyatu dengan litter (kotoran) sehingga hal ini memungkinkan ditemukannya jenis Eimeria yang berbeda-beda. Hal lain yang menyebabkan ditemukan kelima jenis Eimeria adalah tempat yang digunakan pengambilan sampel penelitian merupakan tempat yang lembab. Sehingga kondisi tempat yang lembab ini sangat mendukung perkembangbiakan dari Eimeria spp. Menurut Dawid et.al. (2012) faktor yang menyebabkan didapatkan variasi jenis- 
Tabel 1. Hasil identifikasi koksidia yang ditemukan pada ayam petelur jantan di Peternakan mandiri Kelurahan Segalamider, Kecamatan Tanjung Karang Barat, Kota Bandar Lampung

\begin{tabular}{|c|c|c|c|}
\hline No. & Nama spesies & Mikroskopis & Literatur \\
\hline 1. & $\begin{array}{l}\text { E. maxima } \\
\text { (Ookista tidak } \\
\text { bersporulasi) }\end{array}$ & $\begin{array}{l}\text { Perbesaran } 20 \times 10 \\
27,66 \mu \mathrm{m} \times 16,27 \mu \mathrm{m}\end{array}$ & $\begin{array}{l}\text { Perbesaran 20×10 } \\
\text { (Johnson, 1938) }\end{array}$ \\
\hline 2. & $\begin{array}{l}\text { E. tenella } \\
\text { (Ookista tidak } \\
\text { bersporulasi) }\end{array}$ & $\begin{array}{l}\text { Perbesaran } 20 \times 10 \\
33,03 \mu \mathrm{m} \times 23,57 \mu \mathrm{m}\end{array}$ & 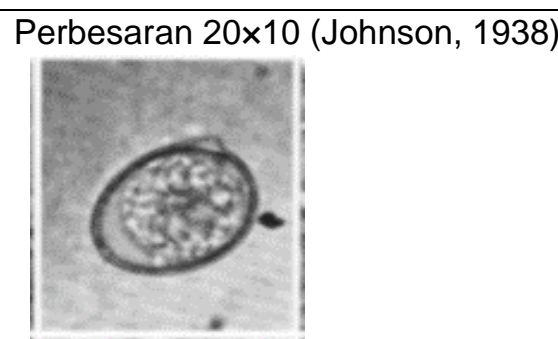 \\
\hline 3. & $\begin{array}{l}\text { E. nikamae } \\
\text { (Ookista tidak } \\
\text { bersporulasi) }\end{array}$ & $\begin{array}{l}\text { Perbesaran } 20 \times 10 \\
33,64 \mu \mathrm{m} \times 16,95 \mu \mathrm{m}\end{array}$ & $\begin{array}{l}\text { Perbesaran } 20 \times 10 \\
\text { (Jadhav et al., 2012) }\end{array}$ \\
\hline 4. & $\begin{array}{l}\text { E. mitis } \\
\text { (Ookista tidak } \\
\text { bersporulasi) }\end{array}$ & $\begin{array}{l}\text { Perbesaran } 20 \times 10 \\
15,2 \mu \mathrm{m} \times 11,3 \mu \mathrm{m}\end{array}$ & $\begin{array}{l}\text { Perbesaran 20×10 } \\
\text { (Johnson, 1938) }\end{array}$ \\
\hline 5. & $\begin{array}{l}\text { E. brunetti } \\
\text { (Ookista tidak } \\
\text { bersporulasi) }\end{array}$ & $\begin{array}{l}\text { (6) } \\
\text { Perbesaran } 20 \times 10 \\
20,2 \mu \mathrm{m} \times 17,4 \mu \mathrm{m}\end{array}$ & $\begin{array}{l}\text { Perbesaran } 20 \times 10 \\
\text { (Jadhav and Susheel, 2014) }\end{array}$ \\
\hline 6. & $\begin{array}{l}\text { E. tenella } \\
\text { (Ookista bersporulasi) }\end{array}$ & $\begin{array}{l}\text { (C)33 } \\
\text { Perbesaran } 10 \times 10 \\
15,6 \mu \mathrm{m} \times 10,8 \mu \mathrm{m}\end{array}$ & $\begin{array}{l}\text { Perbesaran } 20 \times 10 \\
\text { (Johsnon, 1938) }\end{array}$ \\
\hline
\end{tabular}


jenis Eimeria spp dalam suatu peternakan adalah kondisi kandang dan manajemen kandang, nutrisi dan sanitasi yang rendah, ras, iklim, kondisi geografis dan keberadaan ookista di lingkungan.

Jumlah sampel yang terinfeksi, prevalensi dan jumlah OPG dari jenis Eimeria dapat dilihat pada Tabel 2. Jenis parasit pada hasil penelitian ditemukan dalam stadium ookista. Ookista yang ditemukan adalah ookista yang tidak bersporulasi dan ookista yang bersporulasi.

Tabel 2. Jumlah koksidia dan nilai prevalensi pada stadium oocyst per gram (OPG)

\begin{tabular}{|c|c|c|c|c|}
\hline No. & Jenis & $\begin{array}{c}\text { Jumlah } \\
\text { Feses } \\
\text { Ayam } \\
\text { Terinfek- } \\
\text { si }\end{array}$ & $\begin{array}{c}\text { Preva- } \\
\text { lensi }\end{array}$ & $\begin{array}{l}\text { Jum- } \\
\text { Lah } \\
\text { OPG }\end{array}$ \\
\hline 1. & $\begin{array}{l}E . \\
\text { maxima } \\
\text { (OTB) }\end{array}$ & 25 & $25 \%$ & $\begin{array}{c}42.6 \\
00\end{array}$ \\
\hline 2. & $\begin{array}{l}\text { E. tenella } \\
\text { (OTB) }\end{array}$ & 45 & $45 \%$ & $\begin{array}{l}110 . \\
000 \\
\end{array}$ \\
\hline 3. & $\begin{array}{l}\text { E. } \\
\text { nikamae } \\
\text { (OTB) }\end{array}$ & 12 & $12 \%$ & 7200 \\
\hline 4. & $\begin{array}{l}\text { E. mitis } \\
\text { (OTB) }\end{array}$ & 10 & $10 \%$ & 6000 \\
\hline 5. & $\begin{array}{l}\text { E. } \\
\text { brunetti } \\
\text { (OTB) }\end{array}$ & 29 & $29 \%$ & $\begin{array}{c}46.4 \\
00\end{array}$ \\
\hline 6. & $\begin{array}{l}\text { E. tenella } \\
\text { (OB) }\end{array}$ & 20 & $20 \%$ & 2000 \\
\hline $\begin{array}{l}\text { Ket } \\
\text { (OT } \\
\text { lOE }\end{array}$ & $\begin{array}{l}\text { rangan : } \\
\text { 3) : Ookista } \\
\text { : Ookista }\end{array}$ & sporul & & \\
\hline
\end{tabular}

Pada Tabel 2. jumlah koksidia dalam stadium ookista yang tidak bersporulasi yang paling banyak ditemukan adalah jenis E. tenella sebanyak 45 sampel dan yang ditemukan paling sedikit adalah jenis E.mitis sebanyak 10 sampel. Sedangkan untuk ookista yang bersporulasi, hanya ditemukan dari jenis E. tenella sebanyak 20 sampel. Banyaknya ditemukan ookista yang tidak bersporulasi diduga karena terhambatnya proses sporulasi yang disebabkan oleh kondisi lingkungan kandang yang tidak mendukung proses sporulasi. Pada saat pengambilan sampel, kondisi kandang yang digunakan dalam penelitian adalah kandang yang cukup cahaya dan tidak gelap. Hal lain yang diduga adalah karena kondisi lingkungan sekitar, yaitu kelembaban kandang 80$90 \%$, suhu kandang $33^{\circ} \mathrm{C}-35^{\circ} \mathrm{C}$, dan oksigen yang tidak mendukung terjadinya sporulasi, sehingga menyebabkan ookista yang bersporulasi ditemukan lebih sedikit dibandingkan ookista yang tidak bersporulasi

Menurut Vertommen and Kouwenhoven (1993), proses sporulasi pada ternak ayam disebabkan oleh cahaya, kapasitas kandang per meter luasan, manajemen kandang dan iklim. Apabila kondisi kandang gelap atau kurang cahaya, akan dapat mempercepat proses sporulasi ookista yang akan menyebabkan ookista menjadi infektif.

Banyaknya ookista yang tidak bersporulasi tidak akan menyebabkan koksidiosis, sedangkan untuk jumlah ookista bersporulasi yang sedikit dapat menyebabkan penularan koksidiosis. Hal ini dikarenakan hanya ookista yang bersporulasi yang dapat menyebabkan penularan koksidiosis. Sesuai dengan pernyataan Levine (1985) ookista yang bersporulasi merupakan ookista yang infektif. Penularan koksidiosis akan berlangsung apabila ookista yang bersporulasi termakan oleh ayam.

Prevalensi koksidia tertinggi ditemukan pada jenis $E$. tenella dengan nilai prevalensi sebesar $45 \%$, diikuti oleh $E$. brunetti sebesar 29\%, Eimeria tenella bersporulasi $20 \%$, E. nikamae $12 \%$, dan E. mitis memiliki prevalensi terendah sebesar $10 \%$. E. tenella memiliki nilai prevalensi tertinggi diduga karena $E$. tenella memiliki tingkat patogenitas lebih tinggi dibandingkan $E$. maxima, $E$. brunetti, E. nikamae, dan E. mitis. Hal ini serupa dengan pernyataan Cheng (1961) yang menyatakan prevalensi serangan pada jenis Eimeria disebabkan karena tingkat patogenisitas dari Eimeria. 
Menurut Gordon (1977) proses sporulasi akan terjadi apabila kondisi lingkungan sekitar ookista bersuhu $25^{\circ} \mathrm{C}-32^{\circ} \mathrm{C}$ dengan sehingga akan menyebabkan proses sporulasi berlangsung lebih cepat, yaitu 1-2 hari.

Menurut Tabbu (2002) proses sporulasi yang optimal dapat berlangsung pada suhu $25^{\circ} \mathrm{C}-30^{\circ} \mathrm{C}$ dengan kelembaban yang tinggi (70-100\%) dan diikuti dengan kadar oksigen yang tinggi.

Hasil perhitungan nilai ookista per grain (OPG) pada Tabel 2. menunjukkan bahwa jumlah OPG tertinggi ditemukan dari jenis $E$. tenella dengan jumlah OPG 110.000 ookista, diikuti dengan $E$. brunetti dengan jumlah OPG 46.400 ookista, $E$. maxima dengan jumlah OPG 42.600 ookista, E. nikamae dengan jumlah OPG 7.200 ookista, E. mitis dan E. tenella yang bersporulasi memiliki nilai OPG yang terendah, yaitu masing-masing 6.000 okista dan 2.000 ookista. Menurut Setyawati dan Yuwono (2006) ayam yang diinfeksi 20.000 ookista memperlihatkan gejala klinis yang lebih berat dibandingkan ayam yang diinfeksi 10.000 ookista. Hal ini dapat diartikan semakin tinggi jumlah ookista yang menginfeksi ayam akan mempengaruhi dampak koksidiosis yang ditimbulkan.

Pada saat pengambilan sampel, kondisi ayam telah mengalami hemoragi sehingga feses yang keluar bercampur bersama darah. Hal ini diduga berkaitan dengan ditemukan jumlah OPG E. tenella yang bersporulasi sebanyak 2000 ookista. Menurut Jankiewicz and Schofield (1934) apabila ditemukan kurang dari 150 ookista yang bersporulasi tidak menimbulkan kematian, 150-500 ookista menimbulkan hemoragi (pendarahan) ringan, tetapi tidak menimbulkan kematian, 1000-3000 ookista yang bersporulasi dapat menyebabkan hemoragi berat dan kematian, sedangkan 3000-5000 ookista menimbulkan hemoragi berat dan angka kematian yang tinggi.

\section{KESIMPULAN}

Pada penelitian ini kami menemukan bahwa jenis parasit yang ditemukan pada ayam petelur jantan adalah Eimeria maxima, Eimeria tenella, Eimeria nikamae, Eimeria brunetti, Eimeria mitis, dan parasit penyebab koksidiosis adalah Eimeria tenella. Prevalensi serangan koksidia pada ayam petelur jantan akibat infeksi Eimeria tenella sebesar $20 \%$.

\section{UCAPAN TERIMAKASIH}

Penulis mengucapkan terimakasih kepada Bapak lbu pembimbing atas bimbingan dan dukungan dalam penelitian ini dan kepada Balai Veteriner Lampung yang telah bersedia menjadi tempat penelitian penulis.

\section{DAFTAR PUSTAKA}

Cheng, T. C. (1961). The Biology of Animal Parasites. Tokyo: W.B. Saunders Company Limited.
Colville, J. (1991). Diagnostic Parasitology for Veterinary Technicians. California: American Veterinary Publications.

Conway, D. P., and McKenzie, M. E. (2007). Poultry Coccidiosis Diagnostic and Testing Procedures Third Edition. USA: Blackwell Publishing.

Dawid, F., Amede, Y., Bekele, M.. (2012). Claf coccidiosis in selected dairy farms of Dire Dawa, Eastern Ethiopia. Global Veterinaria. 9(4), 460-464.

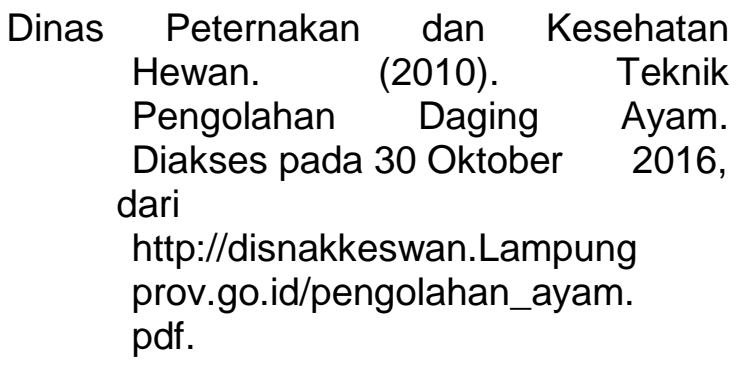


Jadhav, B. N., Bhamre, S. N., dan Dama L. B. (2012). New species of genus Eimeria (Eimeria nikamae) in broiler chicken (Gallus gallus domesticus) from Aurangabad (M.S.) India. Trends in Parasitology Research, 1(3).

Jadhav, B. N., and Susheel, V. N. (2014). Study of Eimeria brunetti (Levine 1942) in broiler chicken from Aurangabad District of Maharashtra State India. International Journal of Applied Science Research and Review, 1(3), 102-106.

Jankiewicz, H. A., dan Schofield, R. H. (1934). The administration of heated oocyts of Eimeria tenella as a means of establishing resistance and ilmmunity to cecal coccidiosis. Jour. Amer. Vet. Med, Assoc. 84, 507-526.

Johnson, W. T. (1938). Coccidiosis of the chicken with special reference to species. Station Bulletin 358, 2-18.
Levine, N. D. (1985). Veterinary Protozoology. Ames: lowa State University Press.

Setyawati, S. J. A dan Yuwono, E. (2006). Upaya peningkatan kekebalan broiler terhadap penyakit koksidoisis melalui infeksi simultan ookista. Jurnal Produksi Ternak, 8(1), 72-77.

Soulsby, E. J. L. (1986). Helminths, Arthropods and Protozoa of Domesticated Animals. 7 rd Ed. London: The English Language Book Society and Bailliere Tindal.
Suratman. (2009). Prevalensi koksidiosis pada ayam di kota Denpasar. Diakses pada 30 Oktober 2016, dari hhtp://www.bulletinveteriner.com/pr evalensi/koksidiosis/ /pada/ayam/Denpasar.

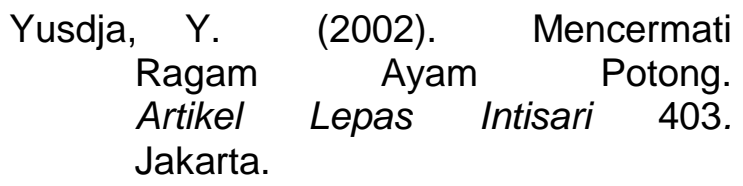

